\title{
SURVIVAL OF SALMONELLAE AND MYCOBACTERIA IN SALTED AND UNSALTED SWINE GUTS USED AS SAUSAGE CASING AND SAUSAGE EMULSION OF A HARD SALAMI
}

\author{
J. PALÁSEK, M. PAVLAS, Iva KUBƯ \\ Veterinary Research Institute, 62132 Brno
}

Received August 24, 1990

\begin{abstract}
Palásek J., M. Pavlas, Iva Kubů: Survival of Salmonellae and Mycobacteria in Salted and Unsalted Swine Guts used as Sausage Casing and Sausage Emulsion of a Hard Salami. Acta vet. Brno, 60, 1991: 375-381.

Salmonellae survived at room temperature $\left(18-22^{\circ} \mathrm{C}\right)$ in salted swine guts used as sausage casing for $7-21$ days. At cooling temperature $\left(4^{\circ} \mathrm{C}\right)$, Salmonella typhimurium was reisolated after revival from control unsalted guts still after 70 days, and in the salted ones even after 154 days. S. enteritidis was less resistant at $4{ }^{\circ} \mathrm{C}$ than $S$. typhimurium, surviving 28 and 126 days in unsalted and salted guts, respectively.

$M$. intracellulare and $M$, avium survived in unsalted guts 91 and 35 days, respectively. In salted guts, the survival of $M$. avium was 6 times longer compared with that in unsalted ones. The dynamics of mycobacterium survival indicate that in salted guts stored at cooling temperature, $M$. avium and $M$. intracellulare are killed within 6 and 12 months, respectively.

During the ripening of a hard salami (Poličan), processed without heat treatment, $S$. enteritidis was reisolated after revival even after 42 days, while, $S$. typhimurium was killed after 35 days already.
\end{abstract}

Swine, Salmonellae, mycobacteria, salted guts, ripening of salami

Salmonellae remain at the top of the list of alimentary infections for a long period and their high resistance against environmental effects has been well documented.

Sodium chloride inhibits the growth of salmonellae at a concentration of $7 \%$ already, but rapid killing only occurs when the concentration reaches $30 \%$ (Koelensmid and van Rhee 1964, cit. Morse and Duncan 1974, Walsh 1972). Temperature is also an important factor for the survival of salmonellae. It has teen demonstrated that at $4-7^{\circ} \mathrm{C}$ salmonellae survived in $10-30 \%$ sodium chloride 106 days at least and that the survival time was 5 times shorter at $18-22{ }^{\circ} \mathrm{C}$ (Herler 1971, cit. Grieger 1978).

High resistance of $M$. avium to chemical and physical effects of the environment is well known (Pavlas and Dokoupil 1967). M. avium survived 1 year in the meal and 5 months in wheat and pea (Kiriljuk 1966). In manure where the conditions for survival of mycobacteria are less favourable, $M$. avium lost its virulence gradually and was killed after $2-3$ months (Sirobokova 1964).

At present, tuberculous lesions are found in the guts of approximately $0.3 \%$ of pigs slaughtered in Czechoslovakia, their findings in parenchymatous organs being rather sporadical. The prevalence represents in the Czech Republic several tens of thousands slaughtered pigs per year, which are released for human consumption under strictly set conditions only. Data on the length of mycobacteria survival in swine guts used as sausage casing and on the effects of salting have not been reported.

Takacs and Simonffy (1970) investigated the survival of salmonellae in ripening salami processed without heat treatment and stated that salmonellae were killed in most cases and that their survival depended on the rate of contamination of the raw sausage emulsion. Complete killing did not occur when the count exceeded $2.10^{4} \cdot \mathrm{g}^{-1}$. 
In Czechoslovakia the survival of salmonellae in hard sausages was studied by Gayer (1978).

The aim of our experiments was to examine the survival times of salmonellae and mycobacteria in salted and unsalted swine guts stored at various temperatures and the fate of salmonellae during the ripening of a hard salami processed without heat treatment.

\section{Materials and Methods}

Mucosa was separated by hand from fresh swine guts, which were then treated with an amount of sodium chloride, corresponding to the original weight of fresh guts. The guts were cut into $20 \mathrm{~cm}$ long segments and one end was tied. Then $0.2 \mathrm{ml}$ of $24 \mathrm{~h}$ broth culture of $S$. typhimurium or $S$. enteritidis was applied into each segment and the other end was tied. Control, unsalted guts were infected similarly. The guts were then stored at $18-22^{\circ} \mathrm{C}$ or at $4{ }^{\circ} \mathrm{C}$.

Samples of the gut wall weighing ca. $1 \mathrm{~g}$ were transferred at regular intervals into $10 \mathrm{ml}$ of buffered peptone water. After $18 \mathrm{~h}$ incubation at $37^{\circ} \mathrm{C}, 0.1 \mathrm{ml}$ of the buffered peptone water was transferred into $10 \mathrm{ml}$ Rappaport medium and $1 \mathrm{ml}$ into $10 \mathrm{ml}$ selenite medium. After another $24 \mathrm{~h}$ of incubation at $42{ }^{\circ} \mathrm{C}$, the samples were inoculated onto agar with brilliant green and phenol red. The growth was evaluated and colonies counted after $24 \mathrm{~h}$ incubation. The incidence of salmonellae was confirmed by the rapid slide agglutination test with a polyvalent serum.

The killing effect of sodium chloride on $M$. avium and $M$. intracellulare was also examined in fresh mucosa-free guts, which were salted, as mentioned above. Ten $\mathrm{cm}$ long segments were infected into the inner side by suspension of mycobacteria, containing $1 \mathrm{mg}$ of culture in $1 \mathrm{ml}$ of sterile physiological saline and $0.5 \mathrm{ml}$ of mycobacterial suspension was inoculated into each segment. Infected guts were stored at $4{ }^{\circ} \mathrm{C}$. Unsalted guts, infected in the same way, were used as a control. Mycobacteria were detected in guts after rinsing in sterile distilled water. The guts were then cut lengthwise and dipped into sterile distilled water for $15 \mathrm{~min}$. After maceration of guts, the liquid was poured off, centrifuged and the sediment was preparated with $\mathrm{HCl}$ and $\mathrm{NaOH}$. After decontamination, the sediment was cultured on solid egg medium and fluid Sula medium. The culture media were incubated at $37^{\circ} \mathrm{C}$ and evaluated in 1-2-week intervals during 2 months.

The sausage emulsion for a herd salami "Poličan" was obtained from a meat plant in Kroměríž. After infection with broth culture of $S$. typhimurium or $S$. enteritidis $\left(10^{3}\right.$ cells per $1 \mathrm{~g}$ of sausage emulsion), the emulsion was filled into original cover and stored hanging in an air-conditioned box "MYTRON" under the conditions valid for this type of salami (Table 1). Humidity was measured with a hygrometer. Samples for salmonella detection were taken in a week intervals and were treated similarly as those of infected swine guts.

\section{Results}

The initial S. typhimurium concentration was $10^{7} \cdot \mathrm{g}^{-1}$ in both salted and unsalted guts (Table 2) at room temperature $18-22{ }^{\circ} \mathrm{C}$. The control showed at first increase of cells up to $10^{9} \cdot \mathrm{g}^{-1}$, but a rapid decrease occurred after 7 days, and after 21 days salmonellae were re-isolated only after revitalization. The decrease of $S$. typhimurium count was even more rapid in salted guts and after 14 days salmonellae were detected even after revitalization.

Table 1

Storing conditions of the sausage emulsion for hard salami "Polixan' infected with salmonella

\begin{tabular}{|c|c|c|}
\hline Period day & Temperature ${ }^{\circ} \mathrm{C}$ & $\begin{array}{c}\text { Relative humidity } \\
\%\end{array}$ \\
\hline $0-14$ & 25 & $85-90$ \\
$15-21$ & 22 & 85 \\
$22-28$ & 19 & 80 \\
$29-35$ & 16 & 75 \\
\hline $36-42$ & 13 & 70 \\
\hline
\end{tabular}


The initial $S$. enteritidis concentration was lower $\left(10^{6} \cdot \mathrm{g}^{-1}\right)$. Increase up to $10^{9} \cdot \mathrm{g}^{-1}$ was recorded at first in unsalted guts, similarly as in S. typhimurium, then the concentration decreased and after 28 days no salmonellae were re-isolated even after revitalization. In salted guts $S$. enteritidis was killed within 14 days. and no salmonellae were re-isolated later.

At the cooling temperature (Table 3) S. enteritidis survived shorter period and was isolated within 28 and 126 days in unsalted and salted guts, respectively.

Mycobacteria survived much longer in swine guts, compared with salmonellae. $M$. intracellulare (Fig. 1), which is more resistant, survived up to 13 weeks, however $M$. avium was killed after 5 weeks. In salted guts the survival of mycobacteria was longer. The survival period in $M$. avium (Fig. 2) was nearly 6 times longer (30 weeks) compared with unsalted guts. $M$. intracellulare survived as long as 7 months in salted guts, but the number of vital ones decrease to about $1 / 3$.

Differences were recorded between the two salmonellae serotypes tested for their survival in the sausage emulsion (Table 4). The number of $S$. typhimurium decreased after 21 days so that they were detectable only after revitalization and after 35 days no salmonellae were reisolated.

Table 2

Survival of salmonellae in salted and unsalted guts at $18-22{ }^{\circ} \mathrm{C}$

\begin{tabular}{|c|c|c|c|c|}
\hline \multirow[t]{2}{*}{ Day } & \multicolumn{2}{|c|}{ S. typhimurium } & \multicolumn{2}{|c|}{ S. enteritidis } \\
\hline & salted & unsalted & salted & unsalted: \\
\hline 0 & $10^{7}$ & $10^{7}$ & $10^{8}$ & $10^{8}$ \\
\hline 1 & $10^{7}$ & $10^{6}$ & $10^{7}$ & $10^{6}$ \\
\hline 3 & $10^{8}$ & $10^{8}$ & $\mathbf{N}$ & $\mathbf{N}$ \\
\hline 7 & $10^{4}$ & $10^{\circ}$ & $10^{5}$ & $10^{8}$ \\
\hline 14 & - & $10^{4}$ & $10^{5}$ & $10^{6}$ \\
\hline 21 & - & + & - & $10^{5}$ \\
\hline 28 & - & - & - & - \\
\hline 35 & - & - & - & - \\
\hline
\end{tabular}

The figures show salmonellae counts per $1 \mathrm{~g}$

+ . . positive after revitalization

N. . not examined

Table 3

Survival of salmonellae in salted and unsalted guts at $+4^{\circ} \mathrm{C}$

\begin{tabular}{|c|c|c|c|c|}
\hline \multirow[t]{2}{*}{ Day } & \multicolumn{2}{|c|}{ S. typhimurium } & \multicolumn{2}{|c|}{ S. enteritidis } \\
\hline & salted & unsalted & salted & unsalted \\
\hline 0 & $10^{7}$ & $10^{7}$ & $10^{6}$ & $10^{\circ}$ \\
\hline 1 & $10^{5}$ & $10^{7}$ & $\mathbf{N}$ & $\mathbf{N}$ \\
\hline 3 & $10^{7}$ & $10^{5}$ & $\mathbf{N}$ & $\mathrm{N}$ \\
\hline 7 & $10^{7}$ & $10^{8}$ & $10^{7}$ & $10^{6}$ \\
\hline 14 & $10^{6}$ & $10^{8}$ & $\mathbf{N}$ & $\mathbf{N}$ \\
\hline 21 & $10^{8}$ & $10^{5}$ & $10^{7}$ & + \\
\hline 28 & $10^{5}$ & $10^{4}$ & $10^{6}$ & + \\
\hline 35 & $10^{4}$ & $10^{3}$ & $10^{5}$ & - \\
\hline 42 & + & + & $10^{5}$ & \\
\hline 49 & + & + & $10^{5}$ & \\
\hline 63 & + & + & + & \\
\hline 70 & + & + & + & \\
\hline 126 & + & - & + & \\
\hline 154 & + & & - & \\
\hline
\end{tabular}


Table 4

Survival of salmonellac during the ripening of hard salami "Polican"

\begin{tabular}{|c|c|c|}
\hline Days & S. typhimurium & S. enteritidis \\
\hline 0 & $10^{3}$ & $10^{3}$ \\
7 & $10^{2}$ & $10^{3}$ \\
14 & + & $10^{2}$ \\
21 & \pm & $10^{2}$ \\
28 & - & + \\
\hline 42 & - & + \\
\hline
\end{tabular}

The firaves show thosed loweount per $1 \mathrm{~g}$ + . Positive after revitalization

$S$. enteritidis was more resistant and was detected by direct culture still after 28 days. This serotype was detectable 42 days after revitalization, which is the period necessary for ripening of the hard salami Poličan.

\section{Discussion}

The survival of salmonellae in guts infected both naturally and artificially and stored in a saturated solution of $\mathrm{NaCl}\left(\mathrm{pH} 4.0\right.$ and 10.0) at $6^{\circ} \mathrm{C}$ was studied by Gabis and Silliker (1974). Under these conditions, salmonellae were killed already after $24 \mathrm{~h}$. If the guts were placed into crystalline sodium chloride, salmonellae were killed after 7 and 21 days in sheep and swine guts, respectively.

Our results demonstrated markedly longer survival periods, especially at cooling temperature, when $S$. typhimurium survived after revitalization 154 and 70 days, in salted and unsalted guts, respectively. $S$. enteritidis was less resistant under the same conditions and survived 126 and 28 days, respectively.

Long survival of both the serotypes of salmonellae in salted guts demonstrate

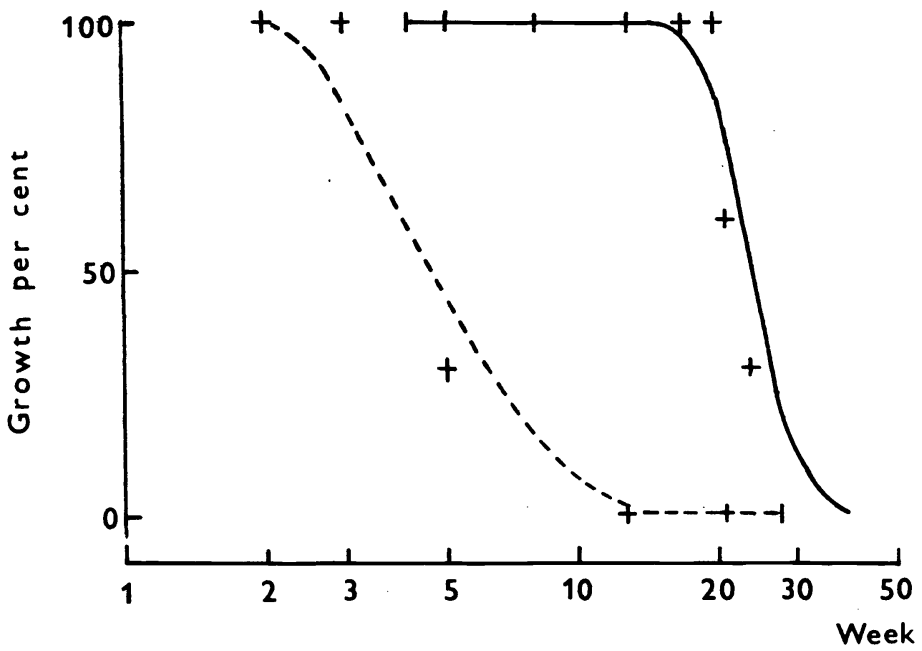

Fig. 1. Survival of $M$. intracellulare 
their great resistance against high concentrations of sodium chloride in the medium.

In salted guts infected with mycobacteria, autolytic influence is apparent with the growth of accompanying psychotrophic microflora. The dynamics of mycobacteria killing shows that in salted guts $M$. avium survives six months and more and $M$. intracellulare even 1 year and more. The data indicate a great resistance of mycobacteria causing the infection of pigs.

The initial salmonellae count is important for their survival in a salami processed without heat treatment. Their killing is explained by the decrease of $a_{w}$ and $\mathrm{pH}$. Takacs and Simonffy (1970) reported that killing od salmonellae is also influenced by catalase activity suppression by produced hydroxylamine. The accumulated hydrogen peroxide is destroying the cells of microorganisms, including salmonellae. Addition of a starting culture to the sausage emulsion of salami processed without heat treatment might significantly shorten the survival time of salmonellae (Gayer 1978). A long survival of salmonellae in another type of hard salami was recorded by Bartas (1982). He re-isolated salmonellae after revitalization 80 days following processing, though the salami was of a very hard consistence. It demonstrates great resistance of salmonellae against drying and decrease of water activity.

Practically it means that salmonellae count hardly exceeds $10^{3} . \mathrm{g}^{-1}$ in the sausage emulsion for hard salami "Poličan". If for all that such a number appears, salmonellae would not been killed during the ripening of salami.

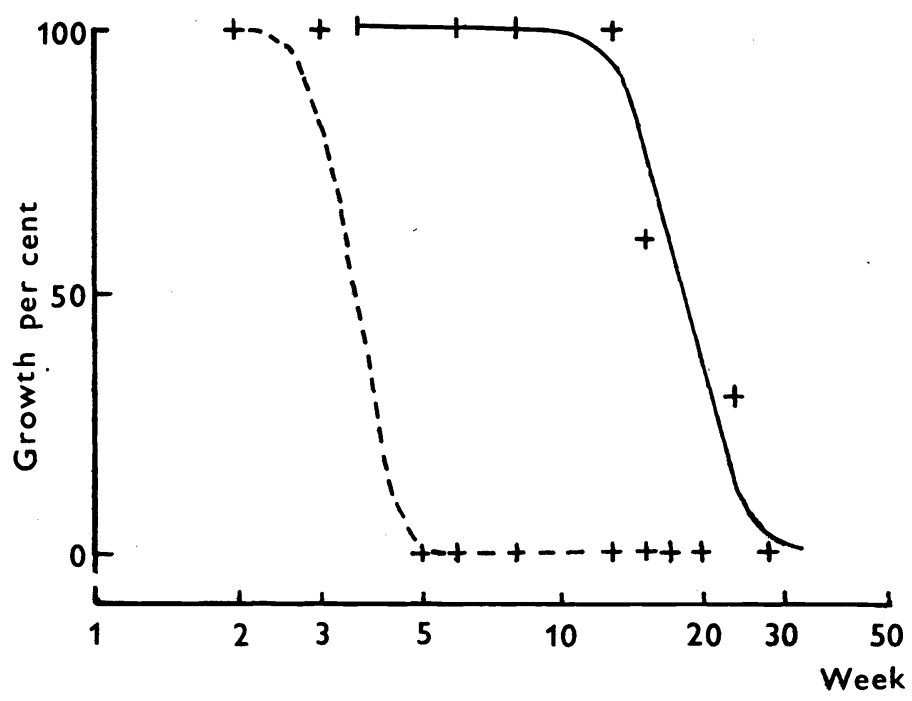

Fig. 2. Survival of $M$. avium medium with $\mathrm{NaCl}$ without $\mathrm{NaCl}-\ldots$

\section{Přežívání salmonel a mykobaktérií $v$ solených a nesolených vepřových střevech a díle trvanlivého masného výrobku}

Při pokojové teplotě $\left(18-22^{\circ} \mathrm{C}\right) \mathrm{v}$ solených střevech přeživaly salmonely do 7. -12 . dne. Při chladírenské teplotě $\left(+4^{\circ} \mathrm{C}\right)$ Salmonella $(S$. ) typhimurium byla $z$ kontrolních nesolených střev zachycena po resuscitaci ještě 70. den, u solených 
dokonce po 154 dnech. $S$. enteritidis při chladírenské teplotě byla méně odolná ve srovnání se $S$. typhimurium, přičemž v nesolených střevech byla zachycena pouze do 28 dnů; v solených střevech vydržela 126 dnů.

Při posouzení devitalizačního účinku chloridu sodného na Mycobacterium avium a $M$. intracellulare při chladírenské teplotě přežívalo $M$. intracellulare $\mathrm{v}$ nesolených střevech 91 dní, $M$. avium 35 dní. U solených střev probíhala devitalizace mykobaktérii daleko pomaleji. Doba přežívání $M$. avium byla $6 \times$ delší ve srovnání $\mathrm{s}$ nesolenými střevy. $\mathrm{Z}$ dynamiky přežívání mykobaktérií vyplynulo, že $\mathrm{v}$ nasolených střevech se dá předpokládat devitalizace $M$. avium za pưl roku, u $M$. intracellulare až za 1 rok po jejich uložení v chladírenské teplotě.

Sledováním přeživání salmonel při zrání tepelně neopracovaného masného výrobku - trvanlivého salámu typu Poličan byla zjištěna větší odolnost u $S$. enteritidis, která byla izolována po resuscitaci i po 42 dnech na rozdíl od $S$. typhimurium, která bylą devitalizována již po 35 dnech.

\section{Выживание сальмонелп и микобактерий в үсповиях повышенного содержания хлорида натрия}

Исследовали способность сальмонелл и микобактерий комплекса M. avium - intracellulare выживать в соленой кишке свиньи и влияние технологии производства на выживание сальмонелл у теплом необрабатыванных мясных продүктов типа Поличан. При комнатной температуре выживали сальмонелли в соленой кишке до 28-ого дня. Температура холодильника позволяла выживание сальмонелл выше 5 месяцев. S. typhimurium изолировали из контрольной несоленой кишки после ресусцитации еще 70. день, из соленой даже после 156 днях. $S$. enteritidis была в температуре холодильника менее устойчива в сравнении с $S$. typhimurium, ее изолировали в несоленой кишке только до 28-ого дня.

Исследованием выживания сальмонелл на протяжении созревания геплом необработанного мясного продукта - салами длительного хранения типа Поличан - определили высшую устойчивость у $S$. enteritidis, которую изолировали после ресусцитации через 6 недель, в сравнении с $S$. typhimurium которая погибала до 5 недель.

При оценке действия хлорида натрия на $M$. avium - intracellulare в температуре холодильника докладывали, что $M$. intracellulare выживало в несоленых кишках до 13 недель, М. авиүм 5 недель. В сопеных кишках происходило разрушение микобактерий значительно медленее. Срок выживания $M$. avium был шесть раз дольше чем у несоленой кишки. Из динамики выживания микобактерий стало ясно, что в соленых кишках можно предполагать гибель $M$. avium через пол года, гибель $M$. intracellulare через год при их хранении в температуре холодильника.

\section{References}

BARTAS, M.: Problematika salmonel u loveckých salámů. Veterinářství, 32, 1982: 176-178: GABIS, D. A.-SILLIKER, J. H.: Salmonella in natural animal casing. Appl. Microbiol., 27, 1974: $66-71$ 
GAYER, P.: Využití startovacích kultur mikroorganismů $k$ výrobě tepelně neopracovaných masných výrobků - I. Zpravodaj masného prủmyslu, č. 3-4, 1978: 32-35

GRIEGER, C.: Vplyv technologie a hygieny na výskyt mikroorganizmov niektorých alimentárných ochorení $\mathrm{v}$ poživatinách. (Habilitačni práce.) Vysoká škola veterinárska. Košice, 1978: $123 \mathrm{p}$.

KIRILJUK, D. A.: O vyživajemosti mikobakterij tuberkuleza ptičevo tipa v zernofuraže. Uč. zap. Kazan. vet. inst. 97, 1966: 148-150

MORSE, E. V.-DUNCAM, M. A.: Salmonellosis - an environmental health problem. J. Am. vet. med. Ass., 165, 1974: 1 015-1019

PAVLAS, M.-DOKOUPIL, S.: Asanace prostředí zamořeného tuberkulózou. Med. Vet., 1967, UUSVU, Kabinet vet. osvěty, Pardubice: $67-69$

SIROBOKOVA, M. M.: Vyživaemost́ vozbuditelja tuberkuleza v torfjanom navoze. Veterinarija, 41, 10, 1964: $71-74$

TAKACS, J. - SIMONFFY, Z.: Das Salmonellen Problem bei Dauerwursten. Fleischwirtschaft, 50, 1970: $1200-1202$

WALSH, D. E.: Bacteriological aspects of pasta processing. (The Salmonella and Staphylococcus problems.) Macaroni J., 53, 1972: 16 